\title{
Characterization of Magnesium Silicate Hydrate (MSH) Gel Formed by Reacting MgO and Silica Fume
}

\author{
Tingting Zhang ${ }^{1}{ }^{\mathbb{D}}$, Jing Zou ${ }^{1}$, Baomin Wang ${ }^{1}$, Zhenlin $\mathrm{Wu}^{2}$, Yuan Jia ${ }^{3, *}$ and \\ Christopher R. Cheeseman 4 (iD) \\ 1 Faculty of Infrastructure Engineering, Dalian University of Technology, Dalian 116023, China; \\ tingtingzhang@dlut.edu.cn (T.Z.); zou_jing8@mail.dlut.edu.cn (J.Z.); wangbm@dlut.edu.cn (B.W.) \\ 2 School of Optoelectronic Engineering and Instrumentation Science, Dalian University of Technology, \\ Dalian 116023, China; zhenlinwu@dlut.edu.cn \\ 3 Hebei Provincial Key Laboratory of Inorganic Nonmetallic, College of Materials Science and Engineering, \\ North China University of Science and Technology, Tangshan 063210, China \\ 4 Department of Civil and Environmental Engineering, Imperial College London, London SW7 2AZ, UK; \\ c.cheeseman@imperial.ac.uk \\ * Correspondence: jia132012@ncst.edu.cn; Tel.: +86-0315-8805020
}

Received: 6 April 2018; Accepted: 24 May 2018; Published: 28 May 2018

\begin{abstract}
Magnesium silicate hydrate (MSH) gel was formed by reacting magnesium oxide (MgO) with silica fume (SF) in distilled water. The MSH was prepared using a $\mathrm{MgO} / \mathrm{SF}$ molar ratio of 1.0 (40:60 weight ratio). Samples were analyzed during hydration process up to 300 days at room temperature. The MSH characterization has been carried out using a range of analytical techniques. Quantitative analysis was achieved using thermogravimetric analysis (TG/DTG) with a de-convolution technology. The structure of MSH gel was characterized using solid state nuclear magnetic resonance $\left({ }^{29} \mathrm{Si}\right.$ NMR) and Fourier transform infrared (FT-IR) spectroscopy. Transmission electron microscopy (TEM) was used to investigate MSH microstructure. Compared with natural magnesium silicate hydrate minerals, the structure of MSH gel is highly disordered and generates on the surface of particles, producing a shell structure with cavity. The molecular structure of MSH phase is layered. The results also show that the extent of polymerization of MSH gel is related to the solution $\mathrm{pH}$ during hydration.
\end{abstract}

Keywords: hydration products; amorphous material; microstructure; $\mathrm{MgO}$; silica fume

\section{Introduction}

The $\mathrm{MgO}-\mathrm{SiO}_{2}-\mathrm{H}_{2} \mathrm{O}$ system has been reported to have potential application for radioactive waste encapsulation [1-7]. Brew and Glasser have prepared magnesium silicate hydrate (MSH) gel by mixing $\mathrm{Na}_{2} \mathrm{SiO}_{3} \cdot 5 \mathrm{H}_{2} \mathrm{O}$ and $\mathrm{Mg}\left(\mathrm{NO}_{3}\right)_{2} \cdot 6 \mathrm{H}_{2} \mathrm{O}$ solutions at $20-25{ }^{\circ} \mathrm{C}$ and studied the alkali $(\mathrm{K}, \mathrm{Cs})$ sorption potential of the resultant synthetic gels [8,9]. The reduced $\mathrm{pH}$ of $\mathrm{MSH}$ formed by $\mathrm{MgO}-\mathrm{SiO}_{2}-\mathrm{H}_{2} \mathrm{O}$ means this system has potential to be used for the encapsulation of mixed Aluminum and $\mathrm{Mg}(\mathrm{OH})_{2}$-rich (Magnox) wastes resulting from the nuclear industry $[4,6]$. The high alkaline pore solution in traditional radioactive waste repositories can result in a series of alterative reaction products and physicochemical changes over extended periods of time (such as the dissolution of clays) [10-13]. MSH cement with $\mathrm{pH}$ values $9.5-10.5$ is within the range required for lower-pH $(<11)$ cements to be considered to improve overall cement-clay compatibility $[14,15]$. In addition, good mechanical properties and thermodynamic stability of reaction produce in the $\mathrm{MgO}-\mathrm{SiO}_{2}-\mathrm{H}_{2} \mathrm{O}$ system have been reported [16-18]. Due to the unique properties of the generated MSH gel, the understanding of the reaction mechanism and characterization of the microstructure and molecular structure have been studied recently [19-39]. 
MSH gel is the main hydration product of the $\mathrm{MgO}-\mathrm{SiO}_{2}-\mathrm{H}_{2} \mathrm{O}$ system. Despite its amorphous nature and lack of long range order, its structure at the local scale can be expected to bear resemblance to crystalline magnesium silicates. There are two different crystal structure models for natural magnesium phyllosilicates, the serpentine-like model [21,22] (T-O layers; antigorite, chrysotile, lizardite [23-28]) and the talc-like model [26,27] (T-O-T layers; talc, sepiolite, palygorskite), where T indicates a sheet of interconnected $\mathrm{Si}-\mathrm{O}$ tetrahedral and $\mathrm{O}$ stands for a sheet of $\mathrm{Mg}-\mathrm{O}$, which octahedrally coordinates to hydroxyl groups and to the apical oxygen atoms of the T sheet(s) [29].

${ }^{29} \mathrm{Si}$ nuclear magnetic resonance spectroscopy (NMR) studies of these minerals have shown important molecular structure information. The serpentine-like model (T-O): ${ }^{29} \mathrm{Si}$ NMR of chrysotile shows the major signal at $-87.6 \mathrm{ppm}$, while the spectrum of serpentine exhibits one strong signal at $-94.0 \mathrm{ppm}$ due to difference in the interconnected $\mathrm{Si}-\mathrm{O}$ tetrahedral angle in the molecular structure [30-32]. The talc-like model (T-O-T): the chemical shift for talc is $-98 \mathrm{ppm}$ and this represents the normal T-O-T layers found in magnesium silicates [8,33,34]. Distinguish from typical T-O-T layered mineral (talc), the major signals of sepiolite are at $-92 \mathrm{ppm},-95 \mathrm{ppm}$ and $-98 \mathrm{ppm}$, respectively [23]. ${ }^{29} \mathrm{Si} \mathrm{NMR}$ exhibits resonance at $-98 \mathrm{ppm}$ due to the $\mathrm{Q}^{3}$ unit in the internal $\mathrm{Si}-\mathrm{O}$ tetrahedral layer and resonance at $-92 \mathrm{ppm}$ due to the $\mathrm{Q}^{3}$ unit via inverted $\mathrm{Si}-\mathrm{O}-\mathrm{Si}$ linkages [29]. Inverted $\mathrm{Si}-\mathrm{O}-\mathrm{Si}$ linkages can cause open channels [34]. ${ }^{29} \mathrm{Si}$ nuclear magnetic resonance spectroscopy (NMR) spectroscopy is most sensitive to the local ordering and structure around the spin nucleus and this permits structural studies not only of crystalline minerals but also of poorly crystalline silicate amorphous materials, such as MSH gel. The molecular structure analysis on MSH gel via ${ }^{29} \mathrm{Si}$ NMR needs to depend on data of natural minerals.

MSH gel, precipitated by a mechanochemical process $\left(\mathrm{Mg}(\mathrm{OH})_{2}, \mathrm{MgO}\right.$ and silicic acid), are determined by X-ray diffraction (XRD) to be poorly crystalline mixes of talc- and serpentine-like minerals, which is similar to the MSH gel produced hydrothermally by mixing $\mathrm{Mg}\left(\mathrm{NO}_{3}\right)_{2} \cdot 6 \mathrm{H}_{2} \mathrm{O}$ and $\mathrm{Na}_{2} \mathrm{SiO}_{3} \cdot 5 \mathrm{H}_{2} \mathrm{O}$. There is also evidence that disordered MSH occurs naturally. Mitsuda [27] reports that MSH gel may be an intermediate product in the formation of talc. Solid-state ${ }^{29} \mathrm{Si} \mathrm{NMR}$ results indicate formation of a serpentine-like material at higher $\mathrm{Mg}$ contents, whereas lower $\mathrm{Mg} / \mathrm{Si}$ gel produces more talc-like structures [8]. Fourier transform infrared spectroscopy (FT-IR) is also a useful tool to study amorphous gels and hydrated minerals. It is sensitive to vibrational modes, thereby indirectly provides information of the local atomic structure $[35,36]$. Natural magnesium silicate hydrate minerals show FT-IR absorption bands in four different regions, such as the $\mathrm{Si}-\mathrm{O}$ vibration region $\left(400-800 \mathrm{~cm}^{-1}\right)$, Si-O stretching region (800-1300 $\left.\mathrm{cm}^{-1}\right), \mathrm{H}_{2} \mathrm{O}$ and $\mathrm{OH}$ vibration region $\left(1300-1800 \mathrm{~cm}^{-1}\right)$ and $\mathrm{H}_{2} \mathrm{O}$ and $\mathrm{OH}$ stretching region $\left(2800-4000 \mathrm{~cm}^{-1}\right)$ [33,34,37-39]. The absorption bands of MSH gel can also reveal some unique properties of the material.

In this work SF, an amorphous silica byproduct from silicon and ferrosilicon production, is used to react with light-burned $\mathrm{MgO}$ to form $\mathrm{MSH}$ gel. Samples are cured for up to 300 days at room temperature. The aim of the research is to understand the role of chemical reaction processes in MSH formation by quantitative analysis and the microstructure of the $\mathrm{MSH}$ phase. Hence $\mathrm{MgO}-\mathrm{SiO}_{2}-\mathrm{H}_{2} \mathrm{O}$ samples have been prepared and the reaction products are analyzed with various characterization techniques.

\section{Materials and Methods}

\subsection{Sample Preparation}

Light burned technical grade magnesium oxide with $\mathrm{MgO}$ activity index of $18 \mathrm{~s}$ was used in all experiments (Martin Marietta Magnesia Specialties, LLC., Manistee, MI, USA, MagChem ${ }^{\circledR}$ Grade 30). SF was obtained from Elkem Materials Ltd., Shanghai, China (Elkem Microsilica ${ }^{\circledR}$ Grade 955). The characterization data from the suppliers of the MgO and SF is given in Table 1. 
Table 1. Characteristics of the raw materials (manufacturer data).

\begin{tabular}{ccc}
\hline Oxide (wt \%) & MgO & SF \\
\hline $\mathrm{MgO}$ & 97.2 & 1.18 \\
$\mathrm{CaO}$ & 0.80 & 0.68 \\
$\mathrm{SiO}_{2}$ & 0.35 & 93.71 \\
$\mathrm{Fe}_{2} \mathrm{O}_{3}$ & 0.15 & 0.24 \\
$\mathrm{Al}_{2} \mathrm{O}_{3}$ & 0.10 & 0.23 \\
$\mathrm{Na}_{2} \mathrm{O}$ & - & 0.35 \\
$\mathrm{~K}_{2} \mathrm{O}$ & - & 1.74 \\
$\mathrm{SO}_{3}$ & 0.02 & 0.37 \\
$\mathrm{P}_{2} \mathrm{O}_{5}$ & - & 0.38 \\
$\mathrm{Cl}$ & 0.35 & - \\
Loss in ignition & 1.03 & 1.12 \\
Bulk Density, loose $\left(\mathrm{g} / \mathrm{cm}^{3}\right)$ & 0.35 & 0.28 \\
Mean Particle Size $(\mu \mathrm{m})$ & 6.7 & 0.3 \\
BET surface area $\left(\mathrm{m}^{2} / \mathrm{g}\right)$ & 26 & 18 \\
\hline
\end{tabular}

$\mathrm{MgO}$ and SF reacted in aqueous solutions at a 1:1 molar ratio (40:60 weight ratio). In order to aid full reaction, an excess water to solids (W/S) ratio of 10 was used, where $S$ is the total mass of $\mathrm{MgO}$ and SF [40]. Samples were stored at room temperature $\left(25 \pm 1^{\circ} \mathrm{C}\right)$ in $250 \mathrm{~mL}$ sealed polyethylene bottles for up to 300 days. The bottles were gently shaken throughout the hydration period to ensure that a homogenous solution concentration can be maintained for uniform reaction. The $\mathrm{pH}$ during hydration was measured at different curing stages using a $\mathrm{pH}$ meter (PHS-3C, Shanghai INESA and Scientific Instrument Company, Shanghai, China). The solid residue with different curing times was separated using filter paper with a pore size of 30-50 $\mu \mathrm{m}$. The collected solids were soaked in absolute ethyl alcohol for $24 \mathrm{~h}$ to inhibit further hydration reactions and then dried at $40^{\circ} \mathrm{C}$ for $48 \mathrm{~h}$ before characterization.

\subsection{Sample Characterization}

The crystalline phases in hydrated solid residue samples were determined using XRD, (D8 Advance, Bruker, Karlsruhe, Germany, Max $2400 \mathrm{~V}$ diffractometer with $\mathrm{Cu} \mathrm{K} \alpha$ radiation at a scan rate of $0.5^{\circ} 2 \theta \mathrm{min}^{-1}$ ). The residual $\mathrm{MgO}$ content in $\mathrm{MgO} / \mathrm{SF}$ pastes was determined by quantitative $\mathrm{X}$-ray diffraction (Q-XRD, Bruker, Karlsruhe, Germany, $\mathrm{Cu} \mathrm{K} \alpha, 40 \mathrm{kV}$ and $40 \mathrm{~mA}$ ) using the K-value method, with $\mathrm{TiO}_{2}$ used as an internal standard material [41,42]. The ground $\mathrm{MgO}$ and internal standard material $\left(\mathrm{TiO}_{2}\right)$ were uniformly mixed at a mass ratio of 1:1 in a mortar with ethanol. One non-overlapping X-ray diffraction peak of $\mathrm{MgO}$ and $\mathrm{TiO}_{2}$ was chosen. $I_{\mathrm{MgO}}$ and $\mathrm{I}_{\mathrm{TiO} 2}$ are the integral intensity of the diffraction peak of $\mathrm{MgO}$ and $\mathrm{TiO}_{2}$ respectively. $\mathrm{K}_{\mathrm{MgO}}$ is defined as follows:

$$
K_{\mathrm{MgO}}=I_{\mathrm{MgO}} / I_{\mathrm{TiO} 2}
$$

The mixed powders with a mass ratio of $20: 80\left(\mathrm{TiO}_{2}:\right.$ Sample), as control specimens, were homogeneously mixed. The mass percentage of $\mathrm{MgO}$ in the mixture was calculated by Equation (2).

$$
w_{\mathrm{MgO}}=\left(I_{\mathrm{MgO}}^{\prime} / I_{\mathrm{TiO} 2}^{\prime}\right)\left(1 / K_{\mathrm{MgO}}\right)\left(w_{\mathrm{TiO} 2} /\left(100-w_{\mathrm{TiO} 2}\right)\right) \times 100(\%), w_{\mathrm{TiO} 2}=20(\%)
$$

where $w_{\mathrm{MgO}}$ is the mass percentage of $\mathrm{MgO}$ in $\mathrm{MSH}$ system, $I^{\prime}{ }_{\mathrm{MgO}}$ and $I^{\prime}{ }_{\mathrm{TiO} 2}$ are equal to the integral intensity of the diffraction peak of $\mathrm{MgO}$ and that of $\mathrm{TiO}_{2}$ in the specimens.

The mass loss of MSH samples was determined using Thermogravimetric analysis (TG/DTG, Mettler Toledo, Zurich, Switzerland). The samples were hold in alumina crucibles and heated in a nitrogen atmosphere from room temperature to $1000{ }^{\circ} \mathrm{C}$ at $10{ }^{\circ} \mathrm{C} \mathrm{min}^{-1}$ heating rate.

The local atomic structure in sample was determined using solid-state high-resolution 29Si NMR (Bruker Advance III $500 \mathrm{MHz}$ spectrometer, Karlsruhe, Germany, field strength $9.4 \mathrm{~T}$, operating 
frequency $79.5 \mathrm{MHz}$ for 29Si). Samples for analysis were packed into $4 \mathrm{~mm}$ zirconia rotors and spun at $8 \mathrm{kHz}$. The 29Si spectra was acquired over 20,000 scans using a pulse recycle delay of $2 \mathrm{~s}$, a $30^{\circ}$ excitation pulse with $2 \mu \mathrm{s}$ width, a relaxation delay of $60 \mathrm{~s}$ and an acquisition time of $0.0426 \mathrm{~s}$. Various atomic nuclei can be quantitatively analyzed as the NMR spectrum area is in proportion to the number of spin nuclei in the same chemical environment. The total range of ${ }^{29} \mathrm{Si}$ chemical shifts in the silicates was considerable, from -60 to $-120 \mathrm{ppm}$, with analytically significant sub-division into well-separated ranges for monosilicates $\left(\mathrm{Q}^{0}\right)$, disilicates and chain end groups $\left(\mathrm{Q}^{1}\right)$, as well as middle groups in chains $\left(\mathrm{Q}^{2}\right)$, chain branching sites $\left(\mathrm{Q}^{3}\right)$ and the three-dimensional cross-linked framework $\left(\mathrm{Q}^{4}\right)$ [43]. ${ }^{29} \mathrm{Si}$ NMR spectra were superimposed by a few resonant peaks [44,45]. De-convolution was applied to assign resonances to individual species using PeakFitv4.12 (Peak separation and analysis software, SeaSolve Software Inc., San Jose, CA, USA).

The vibrational modes of MSH gel were determined using FT-IR. The infrared spectra were recorded using an IR spectrometer (EQUINOX 55, Bruker, Karlsruhe, Germany) with the samples suspended in $\mathrm{KBr}$ discs and pressed at 1.3 $\mathrm{MPa}$. The spectroscopic work was conducted to analyze the broad IR absorption, appearing in the $400-4000 \mathrm{~cm}^{-1}$ region.

The morphological structure of MSH gel was analyzed by transmission electron microscopy (TEM, Tecnai G2 F20/200 kV, FEI NanoPorts, Hillsboro, OR, USA). MSH samples were dispersed in alcohol and maintained as dilute suspension. Then the dilute suspension was dropped onto a copper grid and dried before TEM observation.

\section{Results}

\subsection{XRD Analysis}

Figure 1 shows the phase transformations occurring in the $\mathrm{MgO}-\mathrm{SiO}_{2}-\mathrm{H}_{2} \mathrm{O}$ system with different curing times up to 300 days at room temperature. The two amorphous peaks at $2 \theta\left(35^{\circ}\right)$ and $2 \theta\left(60^{\circ}\right)$ are associated with the formation of $\mathrm{MSH}$. After 7 days, $\mathrm{MgO}$ remains as the major crystalline phase but by 28 days the $\mathrm{MgO}$ has fully reacted to form $\mathrm{Mg}(\mathrm{OH})_{2}$ and amorphous $\mathrm{MSH}$. The consumption of $\mathrm{Mg}(\mathrm{OH})_{2}$ is slow and residual $\mathrm{Mg}(\mathrm{OH})_{2}$ can be observed at 90 days. By 300 days all the $\mathrm{Mg}(\mathrm{OH})_{2}$ has been replaced by amorphous MSH. The main phases in $\mathrm{MgO}-\mathrm{SiO}_{2}-\mathrm{H}_{2} \mathrm{O}$ system include $\mathrm{MgO}$, $\mathrm{Mg}(\mathrm{OH})_{2}$, Silica fume, MSH gel and water.

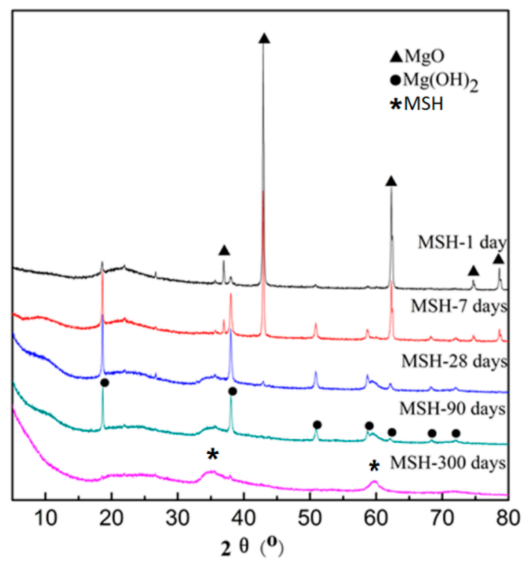

Figure 1. X-Ray diffraction (XRD) results of magnesium silicate hydrate (MSH) samples after curing for $1,7,28,90$ and 300 days.

Based on Q-XRD method (2.2), $w_{M g O}$ ( $n$ days) can be calculated. The consumption percentage of $\mathrm{MgO}\left(\alpha_{\mathrm{MgO}}\right)$ is calculated by Equation (3).

$$
\alpha_{M g O}=\left(w_{M g O}(0 \text { day })-w_{M g O}(n \text { days }) / w_{M g O}(0 \text { day })\right) \times 100(\%)
$$


where $\alpha_{\mathrm{MgO}}$ is consumption percentage of $\mathrm{MgO} . w_{\mathrm{MgO}}$ ( $n$ days) represents residual $\mathrm{MgO}$ mass percentage ( $n$ is $1,7,28,90$ and 300) in MSH system and $w_{M g O}(0$ day) represents initial MgO mass percentage in MSH system. The results are shown in Table 2.

Table 2. Consumption percentage of $\mathrm{MgO}$ at curing time.

\begin{tabular}{ccccccc}
\hline Curing time (day) & 0 & 1 & 7 & 28 & 90 & 300 \\
Consumption percentage of $\mathrm{MgO}(\%)$ & 0 & 7 & 18 & 92 & 100 & 100 \\
\hline
\end{tabular}

\subsection{TG/DTG Analysis}

The corresponding TG/DTG data shows the relative weight loss and derivative weight curves of MSH samples at various ages, see Figure 2a,b. The reaction product is mixed with crystalline and amorphous phases. Attributing to overlapped weight loss peaks, the calculated value is lower than the actual value on the mass loss of MSH phase via traditional thermo-gravimetric analysis method. Based on the derivative thermo-gravimetric (TG/DTG) data, the integration area of derivative curves is equivalent to the weight loss. Therefore, the curve-fitting method based on the de-convolution technology can be used to analyze the DTG curves in order to obtain more precise calculation of each phase. Figure 3 demonstrates the analysis of MSH-28 days using curve-fitting method. Table 3 lists each Gaussian peak data of all the testing samples.

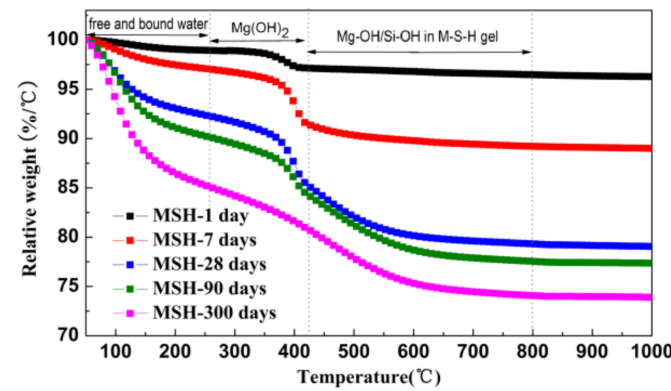

(a)

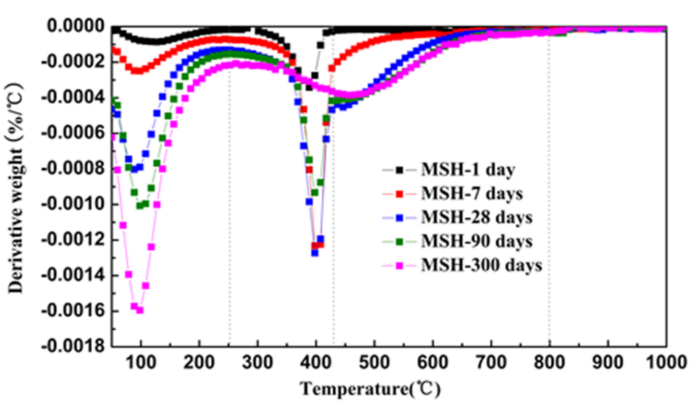

(b)

Figure 2. (a) Thermogravimetric (TG) and (b) Derivative weight curves (DTG) data for MSH samples cured for times up to 300 days.

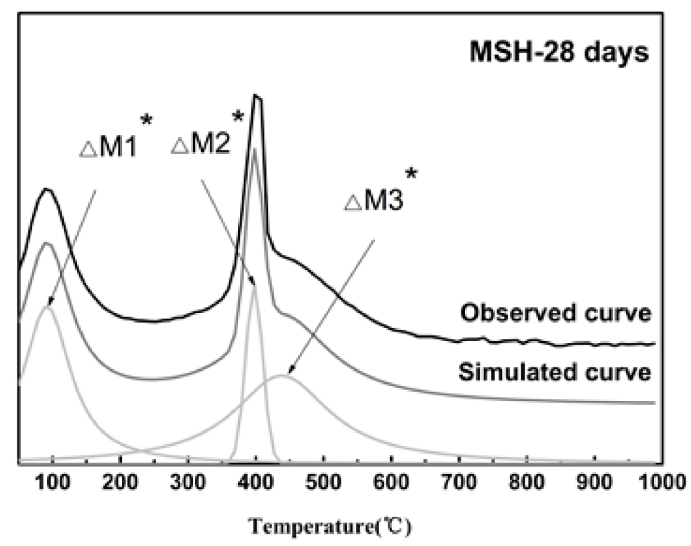

Figure 3. De-convolution of the DTG curves of MSH 28 day sample. The black line is the experimental data. The dark gray line is the global fitting curves and the light gray lines represent the Gaussian peaks on the $\mathrm{x}$-axis obtained by the fitting procedure. 
There are three weight loss stages that can be seen in Figure 2a. The first stage represents the weight loss of free and bound water $\left(\Delta M 1^{*}\right)$ from room temperature to $250{ }^{\circ} \mathrm{C}$. The free and bound water in reaction production increases with curing time. The water loss is related to the mass of MSH gels indirectly. According to the derivative weight curves (DTG) of MSH samples, the second mass loss can be observed in the $250-430{ }^{\circ} \mathrm{C}$ range, attributing to the de-hydroxylation of $\mathrm{Mg}(\mathrm{OH})_{2}\left(\Delta M 2^{*}\right)$. When heating temperature is over $430{ }^{\circ} \mathrm{C}, \mathrm{Mg}-\mathrm{OH}$ and $\mathrm{Si}-\mathrm{OH}$ in $\mathrm{MSH}$ gels continue to remove the hydroxyl group. $\triangle M 3^{*}$ demonstrates the last weight loss stage and is consistent with the formation of MSH gel. The MSH gel content is normally obtained using the third thermo-gravimetric data.

Table 3. Weight loss data at three stages via traditional thermo-gravimetric analysis and using the curve-fitting method.

\begin{tabular}{cccc}
\hline \multirow{2}{*}{ Sample ID } & \multicolumn{3}{c}{ De-Convoluted Data (wt \%) } \\
\cline { 2 - 4 } & $\boldsymbol{\Delta} \mathbf{M 1}^{*}$ & $\boldsymbol{\Delta} \mathbf{M}^{*}$ & $\boldsymbol{\Delta} \mathbf{M}^{*}$ \\
\hline MSH-1 day & $2 \pm 1$ & $1 \pm 1$ & $2 \pm 1$ \\
MSH-7 days & $2 \pm 1$ & $4 \pm 1$ & $4 \pm 1$ \\
MSH-28 days & $8 \pm 2$ & $3 \pm 1$ & $11 \pm 2$ \\
MSH-90 days & $10 \pm 2$ & $2 \pm 1$ & $11 \pm 2$ \\
MSH-300 days & $15 \pm 2$ & - & $11 \pm 2$ \\
\hline
\end{tabular}

The hydroxyl group content of $\mathrm{MSH}$ gel and $\mathrm{Mg}(\mathrm{OH})_{2}$ is confirmed by traditional thermo-gravimetric and curve-fitting method. Compared with DTG result, de-convolution data is more precise. $W_{\mathrm{Mg}(\mathrm{OH}) 2}$ (the mass of $\mathrm{Mg}(\mathrm{OH})_{2}$ ) and $W_{-\mathrm{OH}}$ (the mass of hydroxyl groups of MSH gel) in the mixture are calculated by Equation (4) and Equation (5):

$$
\begin{gathered}
W_{M g(O H) 2}=\left(\Delta M 2^{*} /\left(100-\Delta M 1^{*}-\Delta M 2^{*}-\Delta M 3^{*}\right)\right) \times\left(W_{S F}+W_{M g O}\right) \times M_{\{M g(O H) 2\}} / M_{\{H 2 O\}} \\
W_{-O H}=\left(\Delta M 3^{*} /\left(100-\Delta M 1^{*}-\Delta M 2^{*}-\Delta M 3^{*}\right)\right) \times\left(W_{S F}+W_{M g O}\right)
\end{gathered}
$$

where: $W_{\mathrm{Mg}(\mathrm{OH}) 2}$ and $W_{-\mathrm{OH}}$ are the mass of $\mathrm{Mg}(\mathrm{OH})_{2}(\mathrm{~g})$ and the hydroxyl group of MSH gel (g). $M_{\{\mathrm{Mg}(\mathrm{OH}) 2\}}$ and $M_{\left\{\mathrm{H}_{2} \mathrm{O}\right\}}$ are molar mass of $\mathrm{Mg}(\mathrm{OH})_{2}(\mathrm{~g} / \mathrm{mol})$ and $\mathrm{H}_{2} \mathrm{O}(\mathrm{g} / \mathrm{mol})$. $W_{S F}$ and $W_{M g O}$ are initial mass of SF (g) and $\mathrm{MgO}(\mathrm{g})$, respectively.

\section{3. ${ }^{29}$ Si MAS NMR Spectra}

The ${ }^{29}$ Si MAS NMR spectra of the SF sample show a peak at around -110 ppm, which is assigned to the $\mathrm{Q}^{4}$ unit, see Figure 4. This is consistent with a cross-linked framework formed from silicon-oxygen tetrahedron. Figure 4 also shows the spectra of MSH samples produced at different curing times. The peaks of MSH gel, found at $-80,-85,-92,-97$ and -110 ppm respectively, reveal the decomposition of $\mathrm{SF}$ and the formation of $\mathrm{MSH}$ gel in the $\mathrm{MgO}-\mathrm{SiO}_{2}-\mathrm{H}_{2} \mathrm{O}$ system [46]. According to the literature, the features at $-97,-92,-85$ and $-80 \mathrm{ppm}$ correspond to $\mathrm{Q}^{3}-\mathrm{b}, \mathrm{Q}^{3}-\mathrm{a}, \mathrm{Q}^{2}$ and $\mathrm{Q}^{1}$, respectively [7,29]. In Figure $4, \mathrm{Q}^{3}$ at $-97 \mathrm{ppm}$ disappears after 300 days curing. Chemical shifts located around -100 and $-110 \mathrm{ppm}$ are consistent with $\mathrm{Q}^{3}-\mathrm{SF}$ and $\mathrm{Q}^{4}$ environment (unreacted SF residue). $Q^{3}$-a is assigned to the $\mathrm{Si}$ unit via inverted $\mathrm{Si-O}-\mathrm{Si}$ linkages [29], while $\mathrm{Q}^{3}-\mathrm{b}$ likely reflects the $\mathrm{Si}$ unit in the Si-O tetrahedral layer. The ${ }^{29} \mathrm{Si}$ MAS NMR spectra were de-convolved into different fitted curves based on the ${ }^{29} \mathrm{Si}$ site data. Figure 5 illustrates the analysis of MSH-90 days using curve-fitting method. The data and calculation results from the de-convolution of ${ }^{29} \mathrm{Si} N \mathrm{NR}$ spectra are given in Table 4. The variation tendency of different Si-O tetrahedral environment is shown Figure 6. 
Table 4. ${ }^{29}$ Si nuclear magnetic resonance (NMR) chemical shifts (ppm) and relative intensities (\%) from de-convolution of the ${ }^{29} \mathrm{Si}$ MAS NMR spectra for the MSH samples *.

\begin{tabular}{|c|c|c|c|c|c|c|c|c|}
\hline \multirow[b]{2}{*}{ Sample ID } & \multicolumn{2}{|c|}{$\mathrm{Q}^{1}$} & \multicolumn{2}{|c|}{$Q^{2}$} & \multicolumn{2}{|l|}{$\mathrm{Q}^{3}$} & \multicolumn{2}{|c|}{$\mathrm{Q}^{4}$} \\
\hline & $\begin{array}{l}\text { Center } \\
\text { (ppm) }\end{array}$ & Area $(\%)$ & $\begin{array}{l}\text { Center } \\
\text { (ppm) }\end{array}$ & Area $(\%)$ & Center (ppm) & Area $(\%)$ & $\begin{array}{l}\text { Center } \\
\text { (ppm) }\end{array}$ & Area $(\%)$ \\
\hline SF & - & - & - & - & $101.0\left(\mathrm{sh} / \mathrm{Q}^{3}-\mathrm{SF}\right)$ & $18 \pm 3$ & $-110.2(\mathrm{p})$ & $82 \pm 6$ \\
\hline MSH-1 day & $-80.6(\mathrm{p})$ & $2 \pm 1$ & $-88.9(\mathrm{p})$ & $2 \pm 1$ & $-99.1\left(\mathrm{sh} / \mathrm{Q}^{3}-\mathrm{SF}\right)$ & $22 \pm 3$ & $-110.3(p)$ & $74 \pm 5$ \\
\hline MSH-7 days & $-80.7(\mathrm{p})$ & $4 \pm 1$ & $-85.5(\mathrm{p})$ & $7 \pm 1$ & $\begin{array}{c}-92.1\left(\mathrm{p} / \mathrm{Q}^{3}-\mathrm{a}\right) \\
-98.9\left(\mathrm{sh} / \mathrm{Q}^{3}-\mathrm{SF}\right)\end{array}$ & $\begin{array}{l}10 \pm 1 \\
8.5 \pm 1\end{array}$ & $-110.3(p)$ & $70 \pm 5$ \\
\hline MSH-28 days & $-79.7(p)$ & $6.7 \pm 1$ & $-85.9(\mathrm{p})$ & $21 \pm 2$ & $\begin{array}{l}-92.6\left(\mathrm{p} / \mathrm{Q}^{3}-\mathrm{a}\right) \\
-97.2\left(\mathrm{sh} / \mathrm{Q}^{3}-\mathrm{b}\right)\end{array}$ & $\begin{array}{c}21.7 \pm 3 \\
8.1 \pm 1\end{array}$ & $-112.9(\mathrm{p})$ & $43 \pm 3$ \\
\hline MSH-90 days & $-79.7(\mathrm{p})$ & $11 \pm 1$ & $-85.9(\mathrm{p})$ & $29 \pm 3$ & $\begin{array}{c}-92.3\left(\mathrm{p} / \mathrm{Q}^{3}-\mathrm{a}\right) \\
-96.3\left(\mathrm{sh} / \mathrm{Q}^{3}-\mathrm{b}\right) \\
-100.8\left(\mathrm{sh} / \mathrm{Q}^{3}-\mathrm{SF}\right)\end{array}$ & $\begin{array}{l}33 \pm 3 \\
10 \pm 1 \\
11 \pm 1\end{array}$ & $-109.4(p)$ & $7 \pm 1$ \\
\hline MSH-300 days & $-80.5(p)$ & $6 \pm 1$ & $-85.7(\mathrm{p})$ & $35 \pm 3$ & $\begin{array}{l}-92.6\left(\mathrm{p} / \mathrm{Q}^{3}-\mathrm{a}\right) \\
-97.2\left(\mathrm{p} / \mathrm{Q}^{3}-\mathrm{b}\right)\end{array}$ & $\begin{array}{l}45 \pm 3 \\
14 \pm 1\end{array}$ & - & - \\
\hline
\end{tabular}

${ }^{*} \mathrm{p}$ - peak, sh-shoulder, $\mathrm{Q}^{1}-\mathrm{Q}^{1}(3 \mathrm{OH}), \mathrm{Q}^{2}-\mathrm{Q}^{2}(2 \mathrm{OH}), \mathrm{Q}^{3}-\mathrm{a}-\mathrm{Q}^{3}(\mathrm{OH})$ as continuous layer silicates, $\mathrm{Q}^{3}-\mathrm{b}-\mathrm{Q}^{3}(\mathrm{OH})$ as inverted silicates, $\mathrm{Q}^{3}-\mathrm{SF}-\mathrm{Q}^{3}(\mathrm{OH})$ in $\mathrm{SF}$.

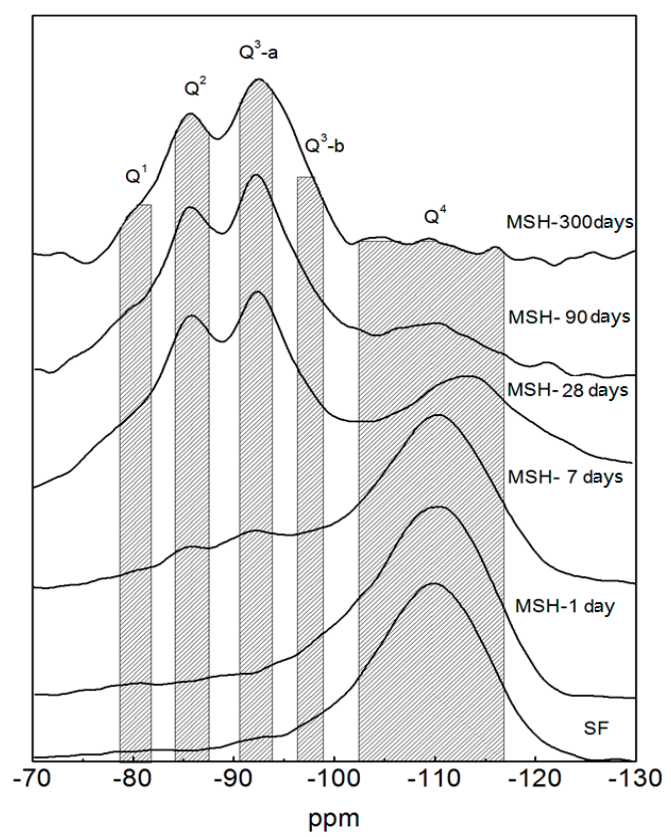

Figure $4 .{ }^{29} \mathrm{Si}$ MAS NMR spectra of the MSH samples for different curing time.

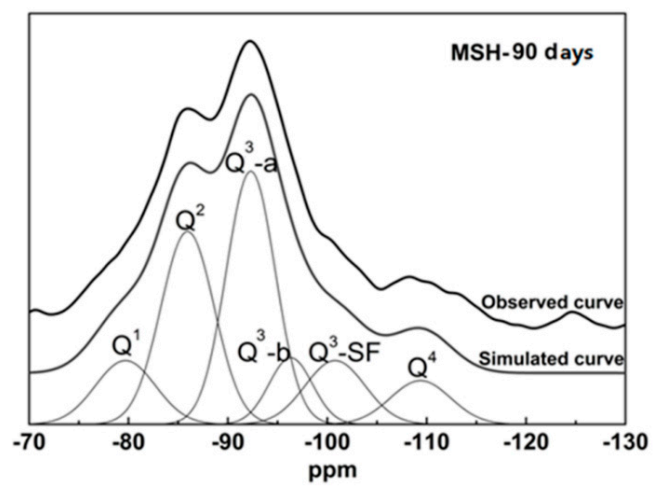

Figure 5. ${ }^{29}$ Si MAS NMR spectrum of the MSH-90 days sample and the optimum de-convolution result. 


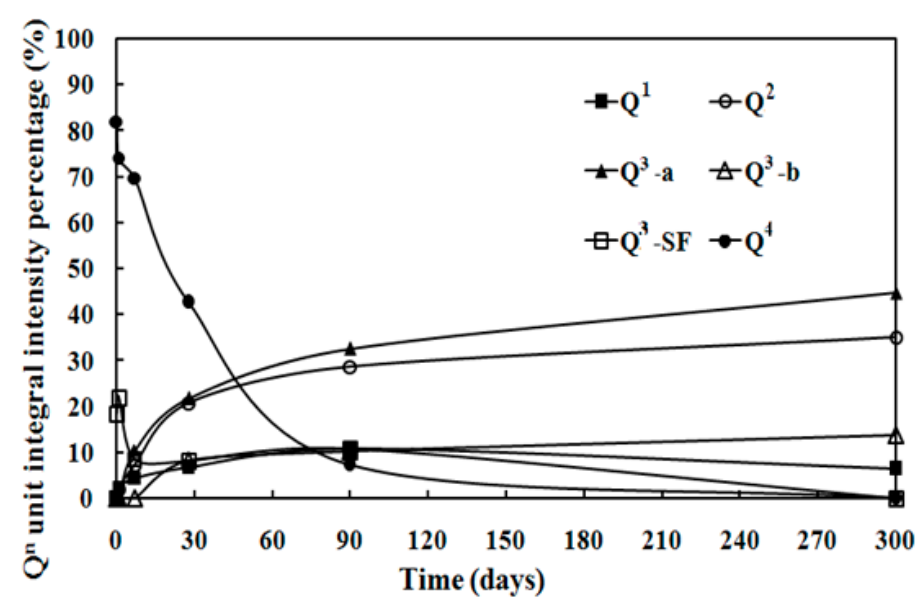

Figure 6. $\mathrm{Q}^{\mathrm{n}}$ unit integral intensity percentage of the MSH samples via ${ }^{29} \mathrm{Si}$ MAS NMR spectra for different curing time.

The sum of $Q^{3}-S F$ and $Q^{4}$ represents residual SF. $I\left(Q^{1}\right), I\left(Q^{2}\right), I\left(Q^{3}\right)$ and $I\left(Q^{4}\right)$ are the integral intensity percentage (\%) of the signals $\mathrm{Q}^{1}, \mathrm{Q}^{2}, \mathrm{Q}^{3}$ and $\mathrm{Q}^{4}$, respectively. $\alpha_{S F}$ (the consumption percentage of SF) is calculated according to Equation (6):

$$
\alpha_{S F}=100-\left(I\left(Q^{4}\right)+I\left(Q^{3}-S F\right)\right)(\%)
$$

where $\alpha_{S F}$ is consumption percentage of SF. Figure 6 indicates that the integral intensity of $\mathrm{Q}^{4}$ can be reduced significantly, while that of $\mathrm{Q}^{2}$ or $\mathrm{Q}^{3}-\mathrm{b}$ increases as the curing time prolongs. The integral intensity of silicon atom with other coordination shows little change.

Meanwhile, the average condensation degree $(C D)$ can be worked out based on ${ }^{29}$ Si MAS NMR data. The average $C D$ reflects the formation process and molecular structure changing tendency of MSH gel. The average $C D$ of samples can be calculated using Equation (7):

$$
C D=\left(3 I\left(Q^{3}-b\right)+3 I\left(Q^{3}-a\right)+2 I\left(Q^{2}\right)+I\left(Q^{1}\right)\right) / 3\left(I\left(Q^{3}-b\right)+I\left(Q^{3}-a\right)+I\left(Q^{2}\right)+I\left(Q^{1}\right)\right)
$$

The $C D$ results of MSH gels are shown in Figure 7. The average condensation degree rises quickly before 7 days and starts to level off ( 0.8). After 90 days, the value slowly goes up to 0.84 .

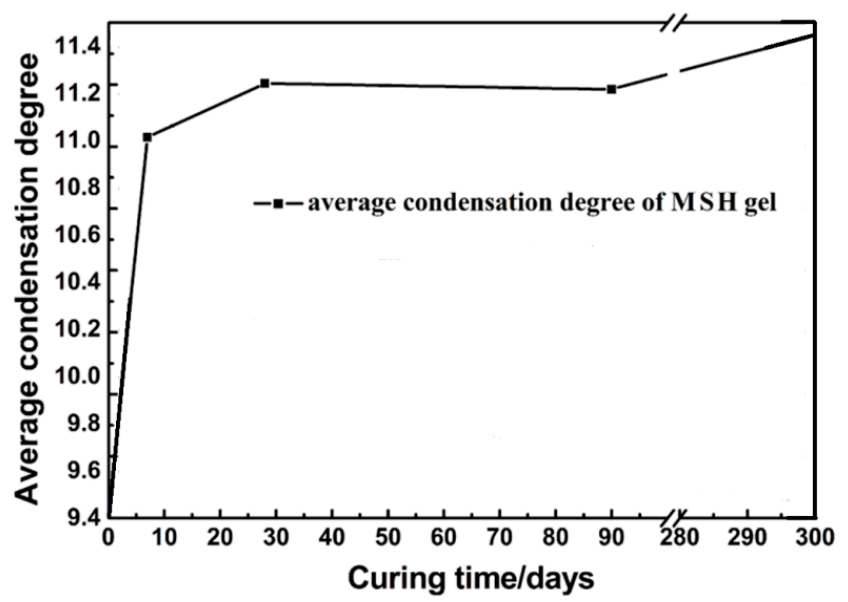

Figure 7. $\mathrm{pH}$ value and average condensation degree of cured MSH gel samples. 


\subsection{FT-IR Spectra}

The FT-IR spectra of the MSH samples show changes in the hydration process of magnesium silicate hydrate cementitious material, indicating the reactions between $\mathrm{MgO}$ and $\mathrm{SiO}_{2}$, as shown in Figure 8. The SF $\left(\mathrm{SiO}_{2}\right)$ shows absorption bands at 1000 1200, 792 and $476 \mathrm{~cm}^{-1}$, typical of four-coordinated silica, which can be assigned to asymmetrical stretching vibration, symmetrical stretching vibration and $\mathrm{Si}-\mathrm{O}$ bending vibration, respectively $[35,36]$. The results also confirm that SF belongs to the framework structure.

As the hydration process progresses, $\mathrm{SF}$ dissolves gradually as the silicon hydroxyl content increases. Figure 8 shows that the band at $1200 \mathrm{~cm}^{-1}$ shifts toward $1010 \mathrm{~cm}^{-1} / 1065 \mathrm{~cm}^{-1}$ (anti-symmetric stretching vibration of Si-O-Mg) and the $800 \mathrm{~cm}^{-1}$ band almost disappears $[39,41,47]$. This suggests that the framework silica atoms change into layer-structured magnesium silicate hydrate. A series of new bands appear from 550 to $650 \mathrm{~cm}^{-1}$ which can be attributed to the symmetric stretching vibration of $\mathrm{Si}-\mathrm{O}-\mathrm{Mg}$ of layer-structured magnesium silicate hydrate $[33,34]$. The band at $3690 \mathrm{~cm}^{-1}$ comes from the $-\mathrm{OH}$ stretching band of $\mathrm{Mg}(\mathrm{OH})_{2}$ and the weak band at $895 \mathrm{~cm}^{-1}$ comes from the stretching vibration of silanol groups $(\mathrm{Si}-\mathrm{OH})[41]$.

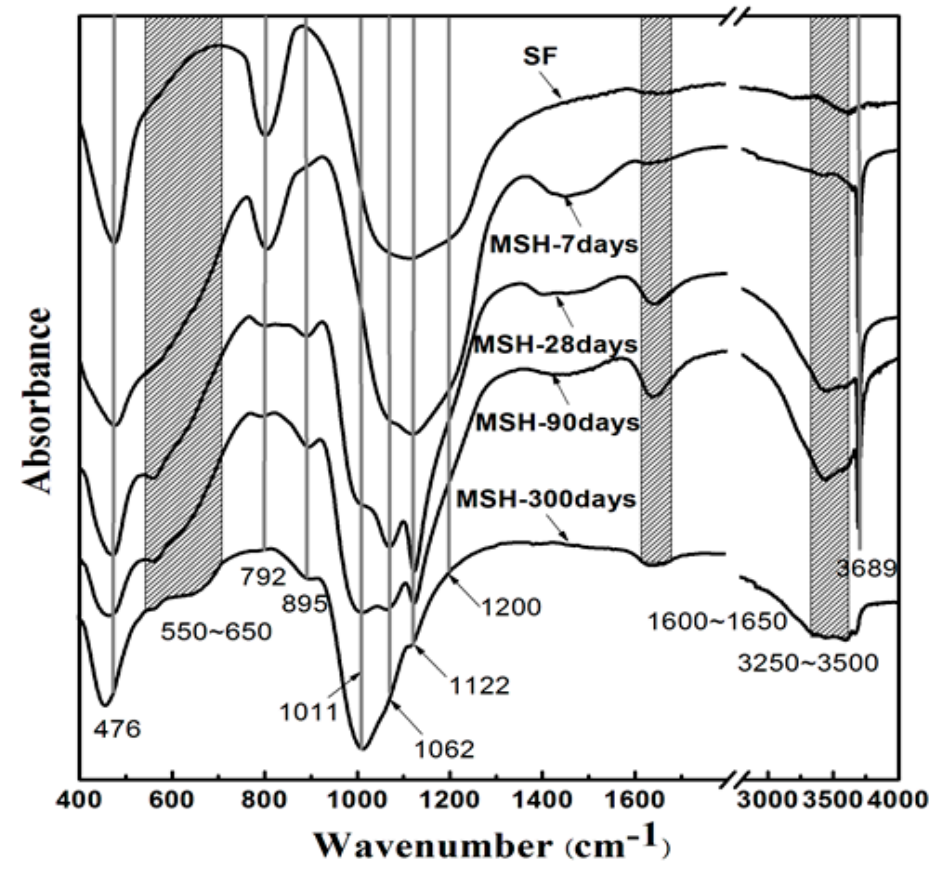

Figure 8. Fourier transform-infrared (FT-IR) spectra of the MSH samples and silica fume.

\subsection{Transmission Electron Microscopy (TEM)}

The micro-structure of reaction products of $\mathrm{MgO}$ and SF is shown in TEM images, see Figure 9. Initially, it can be found that $\mathrm{MgO}$ grains and $\mathrm{SF}$ particles coexist in pore solution from 1 day observation. After 7 days, $\mathrm{MgO}$ is hydrated to form $\mathrm{Mg}(\mathrm{OH})_{2}$ (stick-like morphology) and SF particles are covered in amorphous phase (MSH gel). After 28 days, the amorphous phase (MSH gel) grows around SF particles and the size of SF particles decreases due to the dissolution reaction in alkaline solution. After 90 days, MSH gel forms on the surface of particles but does not grow in the gap between the gel shell and particles. As a result, SF particles eventually dissolve and MSH phases form the shell structure with cavity. 

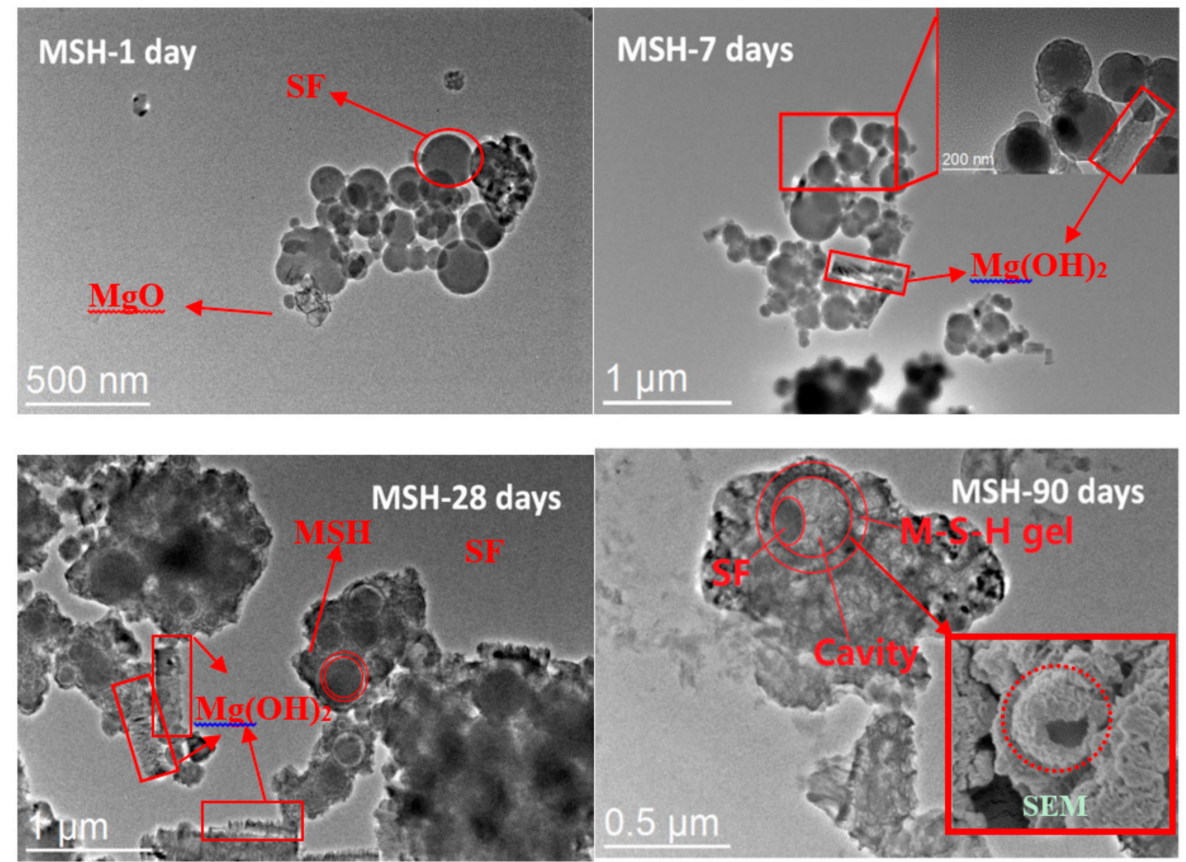

Figure 9. Transmission electron microscopy (TEM) bright field images of samples with different curing times. After 1 day, the spherical particles of the silica fume (SF) can still be found. As curing time extends, the particles gets covered and slowly consumed by MSH gel, forming the shell structure with cavity.

\section{Discussion}

$\mathrm{MgO}$ transforms into $\mathrm{Mg}(\mathrm{OH})_{2}$ and $\mathrm{MSH}$ gel and into $\mathrm{MSH}$ gel eventually. Meanwhile SF gradually transforms into $\mathrm{MSH}$ gel. The mass of water in unreacted $\mathrm{MgO}-\mathrm{SiO}_{2}-\mathrm{H}_{2} \mathrm{O}$ system equals to the mass of chemical structure water $(-\mathrm{OH})$ in $\mathrm{MSH}$ gel with 300 days curing.

According to XRD, TG/DTG and ${ }^{29} \mathrm{Si}$ NMR results, $W_{(\mathrm{MSH} \text { gel })}$ (the mass content of MSH gel) and $W_{\text {(free and bound water) }}$ (free and bound water) with different curing times can be calculated using Equations (8) and (9), as shown in Figure 10.

$$
\begin{gathered}
W_{(\mathrm{MSH} \text { gel })}=\left(\alpha_{\mathrm{MgO}} \times W_{\mathrm{MgO}}-W_{M g(\mathrm{OH}) 2} \times M_{\{\mathrm{MgO} /} M_{\{\mathrm{Mg}(\mathrm{OH}) 2\}}\right)+\alpha_{S F} \times W_{S F}+W_{-\mathrm{OH}} \\
W_{(\text {free and bound water })}=W_{-\mathrm{OH}}(300 \text { days })-\left(M_{\{\mathrm{H} 2 \mathrm{O}\}} / M_{\{\mathrm{Mg}(\mathrm{OH}) 2\}}\right) \times W_{\mathrm{Mg}(\mathrm{OH}) 2}(n \text { days })-W_{-\mathrm{OH}}(n \text { days })
\end{gathered}
$$

where $W_{(\mathrm{MSH} \text { gel) }}$ represents MSH gel formation mass (g) and $W_{(\text {free and bound water) }}$ represents free and bound water mass with different curing times deducting free and bound water mass in MSH gel with 300 days curing. $\alpha_{M g O}$ and $\alpha_{S F}$ are consumption percentage of $\mathrm{MgO}$ and SF. $M_{\{M g O\}}$ and $M_{\{M g(O H) 2\}}$ are molar mass of $\mathrm{MgO}(\mathrm{g} / \mathrm{mol})$ and $\mathrm{Mg}(\mathrm{OH})_{2}(\mathrm{~g} / \mathrm{mol}) . W_{\mathrm{Mg}(\mathrm{OH}) 2}\left(n\right.$ days) and $W_{-\mathrm{OH}}(n$ days) are the mass of $\mathrm{Mg}(\mathrm{OH})_{2}(\mathrm{~g})$ and the hydroxyl groups of MSH gel $(\mathrm{g})$ with different curing times.

The formation of MSH gel is related to the hydrolysis of $\mathrm{MgO}$ and the dissolution of SF. According to quantitative data, phase transformations are shown in Figures 10 and 11. The formation rate of MSH gel is determined by the hydration rate of $\mathrm{MgO}$ and the dissolution rate of SF. Li et al. investigate the performance of $\mathrm{MgO}-\mathrm{SiO}_{2}-\mathrm{H}_{2} \mathrm{O}$ system based on the dissolution rate of $\mathrm{MgO}$ [41]. Figure 11 illustrates the consumption of $\mathrm{MgO}$ and $\mathrm{SF}$ and suggests $\mathrm{MgO}$ reaction rate is faster than SF dissolution rate, leading to the formation of magnesium hydroxide. Slow process plays a key role in a series of reactions. Therefore, MSH gel formation is determined by SF dissolution. 


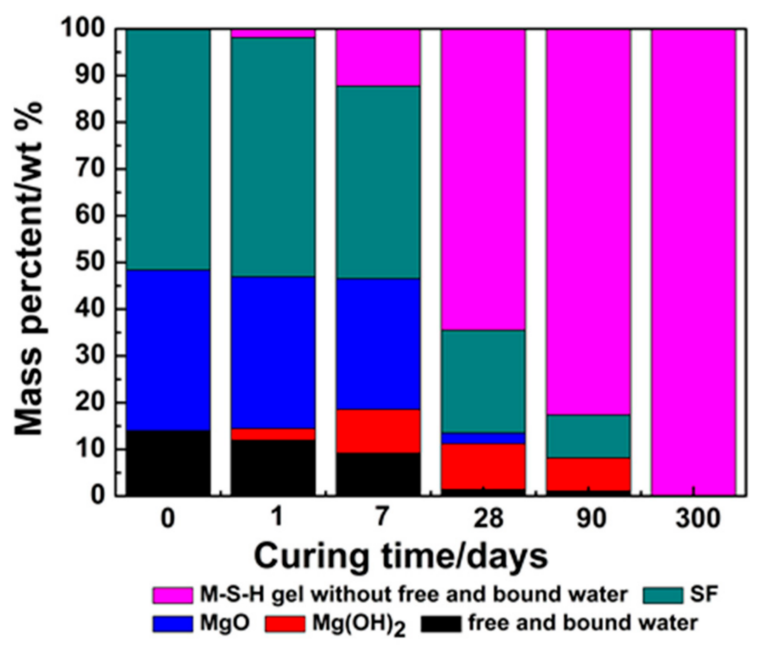

Figure 10. Quantitative analysis of the phase content of MSH samples cured for 300 days via multi-technique approach.

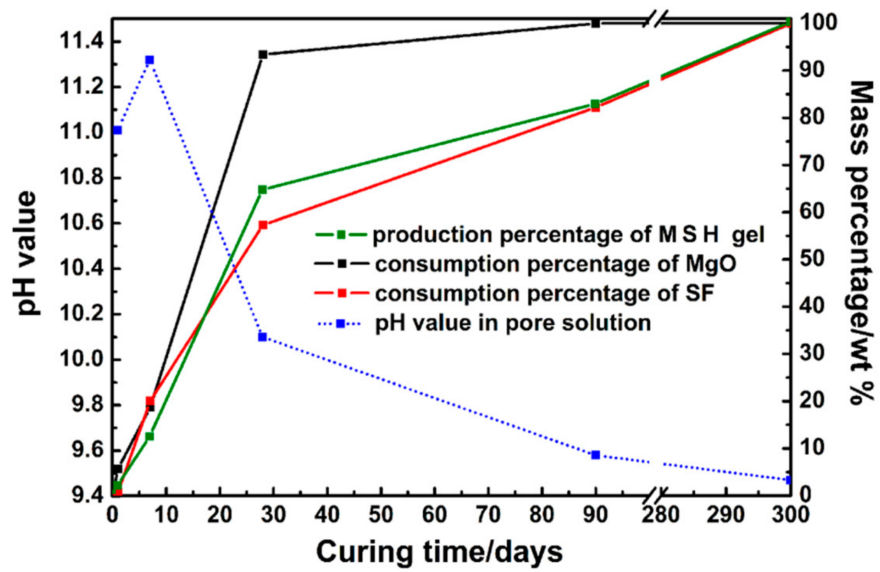

Figure 11. Consumption percentage of $\mathrm{MgO} / \mathrm{SF}$ and production percentage of $\mathrm{MSH}$ gel in $\mathrm{MSH}$ samples cured for 300 days.

The hydrolysis of $\mathrm{MgO}$ affects the $\mathrm{pH}$ value of the solution directly. The $\mathrm{pH}$ value is increased to about 11.3 after 7 days curing and then decreased to 9 after 90 days, see Figure 11. According to the NMR and FT-IR results, SF dissolves quickly during the first 28 days, however, due to the drop of $\mathrm{pH}$ level ( $\mathrm{pH} \approx 9)$, the dissolution rate is then decreases as the curing time grows. MSH gel formed on the surface of SF particles and then the SF particles are gradually consumed by diffusion through the MSH shell. According to Figure 9, MSH gel grows on the surface of particles and towards the solution but not fill the gap between gel shell and particle, contributing to shell structure formation.

From Figures 4-6, it can be found that SF dissolves gradually in alkaline solution. Compared with hydrated magnesium silicate crystal (such as talc model or sepiolite model), the structure of MSH gel is more disordered. On the one hand, $\mathrm{Si}-\mathrm{O}$ ribbons $\left(\mathrm{Q}^{2}\right)$ can be formed and linked via Si unit correspond to $\mathrm{Q}^{3}-\mathrm{b}$, which will result in the formation of hydrated magnesium silicate layers [33,34]. On the other hand, like sepiolite, hydrated magnesium silicate layers link to each other via inverted $\mathrm{Si}-\mathrm{O}-\mathrm{Si}$, while open channels are formed.

The Si-O-Si bond angle of the typical continuous layer silicates $\left(\mathrm{Q}^{3}-\mathrm{b} /-97 \mathrm{ppm}\right)$ is about $120^{\circ}$. The resonance $\left(\mathrm{Q}^{3}-\mathrm{a}\right)$ found at $-92.5 \mathrm{ppm}$ indicates a decrease in $\mathrm{Si}-\mathrm{O}-\mathrm{Si}$ angles. The $\mathrm{Q}^{3}$ unit, via inverted $\mathrm{Si}-\mathrm{O}-\mathrm{Si}$ links, also increases the possibility to form open channels between ribbons [43]. According to TG/DTG data, the adsorbed water molecules in the channels of MSH gel increase as 
curing time grows in Figures 2 and 8. These channels normally contain two types of adsorbed water molecules: one of them is coordinated to magnesium at the edge of octahedral strip and other type is the hydrogen-bonded to the silicate ribbons. The adsorbed water molecule is a key factor in $\mathrm{Si}-\mathrm{O}-\mathrm{Si}$ angle and chemical shift of MSH gel [23].

According to the trends of hydration products content transformation (Figures 1 and 8-11) and the average condensation degree variation of $\mathrm{MSH}$ gel (Figure 7), hydration process of $\mathrm{MgO}-\mathrm{SiO}_{2}-\mathrm{H}_{2} \mathrm{O}$ system can be divided into four stages:

The first period (0-10 days): As soon as $\mathrm{MgO}$ gets into contact with water, there is a rapid consumption of $\mathrm{MgO}$ and $\mathrm{pH}$ value in solution increases to around 11.0. The reaction rate of $\mathrm{SF}$ and $\mathrm{MSH}$ gel is slow. $\mathrm{MgOH}^{+} \cdot \mathrm{OH}^{-}$formation occurs on the surface of $\mathrm{MgO}$ and high $\mathrm{pH}$ value inhibits further hydration. SF dissolution accelerates with time and gradually transforms nesosilicate and dimeric-tetrahedron. Meantime, MSH gel formation rate is limited by magnesium hydroxide precipitation and silicate concentration in solution [47-49]. MSH gel forms on the surface of SF particles.

The second period (10-30 days): In this stage, the reduction in $\mathrm{pH}$ and the increase of magnesium ion and silicate concentration in solution promote the formation of MSH gel [47]. The consumption percentage of $\mathrm{MgO}$ and $\mathrm{SF}$ can reach maximum value and magnesium hydroxide transforms to $\mathrm{MSH}$ gel as well. MSH gel layer thickens and shell structure starts to form. The dissolution rate of SF determines the MSH gel generation. The $\mathrm{Q}^{3}$-a unit, as inverted Si-O tetrahedron, increases significantly and creates open channels between ribbons.

The third period (30-300 days): MSH gel formation rate gradually increases as the SF dissolution rate grows. MSH gel grows on the surface of particles and has contact with the solution, however, it does not grow in the gap between the gel shell and particles, leading to the formation of the shell structure.

\section{Conclusions}

Hydration in the $\mathrm{MgO}-\mathrm{SiO}_{2}-\mathrm{H}_{2} \mathrm{O}$ system can be divided into four stages: pre-induction period (0-1 days), the dormant period (1-10 days), the accelerating period (10-30 days) and the stable period (30-300 days). The $\mathrm{pH}$ value of the pore solution in the $\mathrm{MgO}-\mathrm{SiO}_{2}-\mathrm{H}_{2} \mathrm{O}$ system is directly related to the hydration process. SF dissolution rate is slower than the $\mathrm{MgO}$ reaction rate, which has a key role in MSH gel formation. SF particles gradually dissolve and form a unique, shell structure with cavity. MSH gel forms on the surface of particles and toward the solution and grows on the surface to form a cavity in the gel shell, which is likely to cause shrinkage of the reaction products from the $\mathrm{MgO}-\mathrm{SiO}_{2}-\mathrm{H}_{2} \mathrm{O}$ system. The extent of $\mathrm{Si}-\mathrm{O}$ tetrahedron polymerization in $\mathrm{MSH}$ gels is related to the $\mathrm{pH}$ and ion concentration in the pore solution. There is a unique molecular structure in MSH gel. $\mathrm{Si}-\mathrm{O}$ ribbons, which link with each other via inverted $\mathrm{Si}-\mathrm{O}-\mathrm{Si}$, are formed during the first 7 days of reaction, which leads to the formation of hydrated magnesium silicate layers as the reaction progresses. The $\mathrm{Q}^{3}$ unit, via inverted Si-O-Si links, also enhances the possibility to generate open channels between ribbons while more water molecules are adsorbed in the channels.

Author Contributions: T.Z. and Y.J. conceived and designed the experiments; Y.J. and J.Z. performed the experiments; the paper was written by T.Z., Z.W. and Y.J. under the direction and supervision of B.W. and C.C.

Funding: This research was funded the National Natural Science Foundation of China (Grant No. 51778101; No. 51578108; No. 61704017) and PetroChina Innovation Foundation (2016D-5007-0603).

Acknowledgments: The authors wish to express their gratitude and sincere appreciation for the National Natural Science Foundation of China, Institute of Building Materials (Dalian University of Technology) and Hebei Provincial Key Laboratory of Inorganic Nonmetallic (North China University of Science and Technology).

Conflicts of Interest: The authors declare no conflict of interest. 


\section{References}

1. Gaucher, E.C.; Blanc, P. Cement/clay interactions-A review: Experiments, natural analogues and modeling. Waste Manag. 2006, 26, 776-788. [CrossRef] [PubMed]

2. Zhang, T.T.; Vandeperre, L.J.; Cheeseman, C.R. Bottom-up design of a cement for nuclear waste encapsulation. In Ceramic Materials for Energy Applications; John Wiley \& Sons, Inc.: New York, NY, USA, 2011; pp. 41-49. [CrossRef]

3. Zhang, T.T.; Cheeseman, C.R.; Vandeperre, L.J. Characterization of corrosion of nuclear metal wastes encapsulated in magnesium silicate hydrate (MSH) cement. In Ceramic Materials for Energy Applications II; John Wiley \& Sons, Inc.: New York, NY, USA, 2012; pp. 159-167. [CrossRef]

4. Zhang, T.T.; Vandeperre, L.J.; Cheeseman, C.R. Magnesium silicate-hydrate cements for encapsulating problematic aluminium containing wastes. J. Sustain. Cem. Based Mater. 2012, 1, 34-45. [CrossRef]

5. Berner, U.; Kulik, D.A.; Kosakowski, G. Geochemical impact of a low-pH cement liner on the near field of a repository for spent fuel and high-level radioactive waste. Phys. Chem. Earth 2013, 64, 46-56. [CrossRef]

6. Walling, S.A.; Kinoshita, H.; Bernal, A.; Collier, N.C.; Provis, J.L. Structure and properties of binder gels formed in the system $\mathrm{Mg}(\mathrm{OH})_{2}-\mathrm{SiO}_{2}-\mathrm{H}_{2} \mathrm{O}$ for immobilization of Magnox sludge. Dalton Trans. 2015, 44, 8126-8137. [CrossRef] [PubMed]

7. Walling, S.A. Conversion of Magnesium Bearing Radioactive Wastes into Cementitious Binders. Ph.D. Thesis, University of Sheffield, Sheffield, UK, 2016.

8. Brew, D.R.M.; Glasser, F.P. Synthesis and characterization of magnesium silicate hydrate gels. Cem. Concr. Res. 2005, 35, 85-98. [CrossRef]

9. Brew, D.R.M.; Glasser, F.P. The magnesia-silica gel phase in slag cements: Alkali (K, Cs) sorption potential of synthetic gels. Cem. Concr. Res. 2005, 35, 77-83. [CrossRef]

10. Dauzeres, A.; Le Bescop, P.; Sardini, P.; Cau Dit Coumes, C. Physico-chemical investigation of clayey/ cement-based materials interaction in the context of geological waste disposal: Experimental approach and results. Cem. Concr. Res. 2010, 40, 1327-1340. [CrossRef]

11. Lothenbach, B.; Le, G.S.; Ben, M.H.; Figi, R.; Wieland, E. Hydration of a low-alkali CEM III/B-SiO 2 cement (LAC). Cem. Concr. Res. 2012, 42, 410-423. [CrossRef]

12. Pusch, R.; Zwahr, H.; Gerber, R.; Schomburg, J. Interaction of cement and smectitie clay theory and practice. Appl. Clay Sci. 2003, 23, 203-210. [CrossRef]

13. Honty, M.; De, M.C.; Wang, L.; Madejová, J.; Czímerová, A.; Pentrák, M.; Stríček, I.; Van, M.G. The effect of high $\mathrm{pH}$ alkaline solutions on the mineral stability of the Boom Clay-Batch experiments at $60{ }^{\circ} \mathrm{C}$. Appl. Geochem. 2010, 25, 825-840. [CrossRef]

14. Savage, D.; Walker, C.; Arthur, R.; Rochelle, C.; Oda, C.; Takase, H. Alteration of bentonite by hyper-alkaline fluids: A review of the role of secondary minerals. Phys. Chem. Earth 2007, 32, 287-297. [CrossRef]

15. Kosakowski, G.; Berner, U. The evolution of clay rock/cement interfaces in a cementitious repository for low-and intermediate level radioactive waste. Phys. Chem. Earth 2013, 64, 65-86. [CrossRef]

16. Szczerba, J.; Prorok, R.; Śnieżek, E.; Madej, D.; Maślona, K. Influence of time and temperature on ageing and phases synthesis in the $\mathrm{MgO}-\mathrm{SiO}_{2}-\mathrm{H}_{2} \mathrm{O}$ system. Thermochim. Acta 2013, 567, 57-64. [CrossRef]

17. Chen, Y.; Wei, J. Hydrated Magnesium Silica System Gelling Material Coagulating and Hardening at Normal Temperature and Its Preparation Method. Chinese Patent CN1267374 C, 2 August 2006.

18. Chen, Y.; Wei, J. Hydrated Magnesium Silica and Synthesis Method. Chinese Patent CN1315726 C, 16 May 2007.

19. Lothenbach, B.; Nied, D.; L'Hôpital, E.; Achiedo, G.; Dauzères, A. Magnesium and calcium silicate hydrates. Cem. Concr. Res. 2015, 77, 60-68. [CrossRef]

20. Chiang, W.S.; Ferraro, G.; Fratini, E.; Ridi, F.; Yeh, Y.Q.; Jeng, U.S.; Chen, S.H.; Baglioni, P. Multiscale structure of calcium-and magnesium-silicate-hydrate gels. J. Mater. Chem. A 2016, 2, 12991-12998. [CrossRef]

21. Temuujin, J.; Okada, K.; MacKenzie, K.J.D. Formation of layered magnesium silicate during the aging of hydroxide-silica mixtures. J. Am. Ceram. Soc. 1998, 81, 754-756. [CrossRef]

22. Temuujin, J.; Okada, K.; MacKenzie, K.J.D. Role of water in the mechanochemical reactions of $\mathrm{MgO}^{-\mathrm{SiO}_{2}}$ systems. J. Solid State Chem. 1998, 138, 169-177. [CrossRef]

23. Barron, P.F.; Slade, P.; Frost, R.L. Solid-state silicon-29 spin-lattice relaxation in several 2:1 phyllosilicate minerals. J. Phys. Chem. 1985, 89, 3305-3310. [CrossRef] 
24. Hayashi, H.; Otsuka, H.R.; Imai, N. Infrared study of sepiolite and palygorskite on heating. Am. Mineral. 1969, 54, 1613-1624. [CrossRef]

25. Shuali, U.; Bram, L.; Steinberg, M. Infrared study of the thermal-treatment of sepiolite and palygorskite saturated with organic amines. Thermochim. Acta 1989, 148, 445-456. [CrossRef]

26. MacKenzie, K.J.D.; Meinhold, R.H. The thermal reaction of talc studied by ${ }^{29} \mathrm{Si}$ and ${ }^{25} \mathrm{Mg}$ MAS NMR. Thermochim. Acta 1994, 244, 195-203. [CrossRef]

27. Mitsuda, T.; Taguchi, H. Formation of magnesium silicate hydrate and its crystallization to talc. Cem. Concr. Res. 1977, 7, 223-230. [CrossRef]

28. Tosca, N.J.; Macdonald, F.A.; Strauss, J.V.; Johnston, D.T.; Knoll, A.H. Sedimentary talc in Neoproterozoic carbonate successions. Earth Planet. Sci. Lett. 2011, 306, 11-22. [CrossRef]

29. Tonelli, M.; Martini, F.; Calucci, L.; Fratini, E.; Geppi, M.; Ridi, F.; Borsacchi, S.; Baglioni, P. Structural characterization of magnesium silicate hydrate: Towards the design of eco-sustainable cements. Dalton Trans. 2016, 45, 3294-3304. [CrossRef] [PubMed]

30. Mackenzie, K.J.D.; Meinhold, R.H. Thermal-reactions of chrysotile revisited-a Si-29 and Mg-25 MAS NMR-study. Am. Mineral. 1994, 79, 43-50.

31. Liao, J.; Senna, M. Thermal behavior of mechanically amorphized talc. Thermochim. Acta 1992, 197, $295-306$. [CrossRef]

32. Suquet, H. Effects of dry grinding and leaching on the crystal structure of chrysotile. Clays Clay Miner. 1989, 37, 439-445. [CrossRef]

33. Nied, D.; Enemark-Rasmussen, K.; L’Hopital, E.; Skibsted, J.; Lothenbach, B. Properties of magnesium silicate hydrates (MSH). Cem. Concr. Res. 2016, 79, 323-332. [CrossRef]

34. Roosza, C.; Grangeonb, S.; Blancb, P.; Montouilloutc, V.; Lothenbachd, B.; Henocqa, P.; Giffauta, E.; Vieillarde, P.; Gaboreau, S. Crystal structure of magnesium silicate hydrates (MSH): The relation with 2:1 Mg-Si phyllosilicates. Cem. Concr. Res. 2015, 73, 228-237. [CrossRef]

35. Vidmer, A.; Sclauzero, G.; Pasquarello, A. Infrared spectra of jennite and tobermorite from first-principles. Cem. Concr. Res. 2014, 60, 11-23. [CrossRef]

36. Sáez del Bosquea, I.F.; Martínez-Ramíreza, S.; Blanco-Varela, S. FTIR study of the effect of temperature and nanosilica on the nanostructure of C-S-H gel formed by hydrating tricalcium silicate. Constr. Build. Mater. 2014, 52, 314-323. [CrossRef]

37. Andersen, M.D.; Jakobsen, H.J.; Skibsted, J. Characterization of white Portland cement hydration and the C-S-H structure in the presence of sodium aluminate by ${ }^{27} \mathrm{Al}$ and ${ }^{29} \mathrm{Si}$ MAS NMR spectroscopy. Cem. Concr. Res. 2004, 34, 857-868. [CrossRef]

38. Rulmont, A.; Cahay, R.; Liegeoisduyckaerts, M.; Tarte, P. Vibrational spectroscopy of phosphates-general correlations between structure and spectra. Eur. J. Inorg. Chem. 1991, 28, 207-219.

39. Gunde, M.K. Vibrational modes in amorphous silicon dioxide. Physica B 2000, 292, 286-295. [CrossRef]

40. Hartman, J.S.; Millard, R.L. Gel synthesis of magnesium silicates: A ${ }^{29}$ Si magic angle spinning NMR study. Phys. Chem. Miner. 1990, 17, 1-8. [CrossRef]

41. Li, Z.H.; Zhang, T.S.; Hu, T.S.J.; Tang, Y.; Niu, Y.F.; Wei, J.X.; Yu, Q.J. Characterization of reaction products and reaction process of $\mathrm{MgO}-\mathrm{SiO}_{2}-\mathrm{H}_{2} \mathrm{O}$ system at room temperature. Constr. Build. Mater. 2014, 61, 252-259. [CrossRef]

42. Li, J.X.; Yu, Q.J.; Wei, J.X.; Zhang, T.S. Structural characteristics and hydration kinetics of modified steel slag. Cem. Concr. Res. 2011, 3, 324-329. [CrossRef]

43. Barron, P.F.; Frost, R.L. Solid state ${ }^{29} \mathrm{Si}$ NMR examination of the 2:1 ribbon magnesium silicates, sepiolite and palygorskite. Am. Mineral. 1985, 70, 758-766.

44. Maruyama, I.; Nishioka, Y.; Lgarashi, G.; Matsui, K. Microstructural and bulk property changes in hardened cement paste during the first drying process. Cem. Concr. Res. 2014, 58, 20-34. [CrossRef]

45. Jia, Y.; Wang, B.M.; Zhang, T.T. A Comparative Study of Different Amorphous and Paracrystalline Silica by NMR and SEM/EDS. J. Wuhan Univ. Technol.-Mater. Sci. Ed. 2015, 30, 900-907. [CrossRef]

46. Salomao, R.; Bittencourt, L.R.M.; Pandolfelli, V.C. A novel approach for magnesia hydration assessment in refractory castables. Ceram. Int. 2007, 33, 803-810. [CrossRef] 
47. Vella, E.; Buscarino, G.; Vaccaro, G.; Boscaino, R. Structural organization of silanol and silicon hydride groups in the amorphous silicon dioxide network. Eur. Phys. J. B 2011, 83, 47-52. [CrossRef]

48. Jia, Y.; Wang, B.M.; Wu, Z.L.; Han, J.N.; Zhang, T.T.; Vandeperre, L.J.; Cheeseman, C.R. Role of sodium hexametaphosphate in $\mathrm{MgO} / \mathrm{SiO}_{2}$ cement pastes. Cem. Concr. Res 2016, 89, 63-71. [CrossRef]

49. Jin, F.; Al-Tabbaa, A. Characterization of different commercial reactive magnesia. ICE Adv. Cem. Res. 2014, 26, 101-113. [CrossRef] 